\title{
The Effect of Temperature Curing on Geopolymer Concrete
}

\author{
Triwulan $^{1,2, *}$, Januarti Jaya Ekaputri ${ }^{1,2}$ and Nur Fadlilah Priyanka ${ }^{1}$ \\ ${ }^{1}$ Department of Civil Engineering, Faculty of Civil Engineering and Planning \\ ITS Surabaya, Indonesia, 60111. \\ ${ }^{2}$ Konsorsium Riset Geopolimer Indonesia (KORIGI), Lab Beton dan Bahan Bangunan ITS, Surabaya, \\ Indonesia
}

\begin{abstract}
This study presents curing temperature influences to behaviors of geopolymer concrete. The concrete was fly ash based, with the ratio of fly ash to alkaline activator was $65 \%: 35 \%$. Ratio coarse aggregate to fine aggregate was $60 \%: 40 \%$, ratios $\mathrm{Na}_{2} \mathrm{SiO}_{3} / \mathrm{NaOH}$ were $1.5: 2$ and 2.5 . A polycarboxilate superplasticizer with ratio was $2 \%$ to fly ash weight. Form of the test specimens were cylinder with diameter of $10 \mathrm{~cm}$ and $20 \mathrm{~cm}$ high. Steam curing conducted were at $40^{\circ} \mathrm{C}, 60^{\circ} \mathrm{C}$ and $80^{\circ} \mathrm{C}$ for 24 hours. The control specimens were treated at normal moist curing. Tests conducted were compressive strength, tensile strength, porosity and elasticity modulus. The results indicated that at the elevated temperature the compressive strength increases as well as tensile strength but decreases the closed porosity of specimens. The elasticity modulus had a similar tendency.
\end{abstract}

\section{Introduction}

This paper presents the influence of temperature curing to behaviors of geopolymer concrete. It is already known that manufacturing process of Ordinary Portland Cement (OPC) produce $\mathrm{CO}_{2}$ as pollutants [1]. Since it is a main substantial in concrete industries, an innovative eco-friendly material is necessary to be considered. Recently, geopolymer concrete is introduced as one of the solutions. It is formed by using source materials containing reactive silica $\left(\mathrm{SiO}_{2}\right)$ and alumina $\left(\mathrm{Al}_{2} \mathrm{O}_{3}\right)$ activated with alkali solutions. The source of materials can be obtained abundantly, such as fly ash (FA), calcined clay, metakaolin or granulated blast furnace slag (GBFS) [1,2]. Researches on geopolymers mostly were application of class $\mathrm{F}$ fly ash mixed with activator alkali to produce high strength geopolymer paste [4]. In general, mixing class $\mathrm{F}$ fly ash and activator alkali with mass ratio of $\mathrm{Na}_{2} \mathrm{SiO}_{3}$ to $\mathrm{NaOH}$ in the range of 1.5-2.0 resulted in high compressive strength of geopolymer concrete. In this case, the consentration of $\mathrm{NaOH}$ was eight molars [4]. In some countries the geopolymer concrete are applied as structure members [5]. It is normal in concrete that curing factors have an effect on the compressive strength, as well as

\footnotetext{
*Corresponding author: triwulan_marwan@yahoo.com
} 
for geopolymer concrete. At elevated temperature of curing, the strength of concrete has tendency to increase.

\section{Materials and experiments}

The concrete was based on fly ash. The mass ratio fly ash to alkali activator was $65 \%$ : $35 \%$, mass ratio of coarse aggregate to fine aggregate was $60 \%: 40 \%$, and mass ratio $\mathrm{Na}_{2} \mathrm{SiO}_{3}$ to $\mathrm{NaOH}$ were varied at $1.5,2,2.5$. Superplasticizer used was polycarboxilate based with a ratio of $2 \%$ by fly ash weight. In this paper, geopolymer concrete were prepared for cylindrical specimens with a diameter of $10 \mathrm{~cm}$ and $20 \mathrm{~cm}$ high. After casting, the specimens were steam cured at temperature varied at $40^{\circ} \mathrm{C}, 60^{\circ} \mathrm{C}$ and $80^{\circ} \mathrm{C}$. Some tests were performed for compressive strength, tensile strength and elasticity modulus. Some specimen controls were treated at room temperature.

\section{Experimental results}

\subsection{Material analysis.}

The results XRD analysis of fly-ash is shown in Figure 1 and Table 1, and XRF result is illustrated in Table 2.

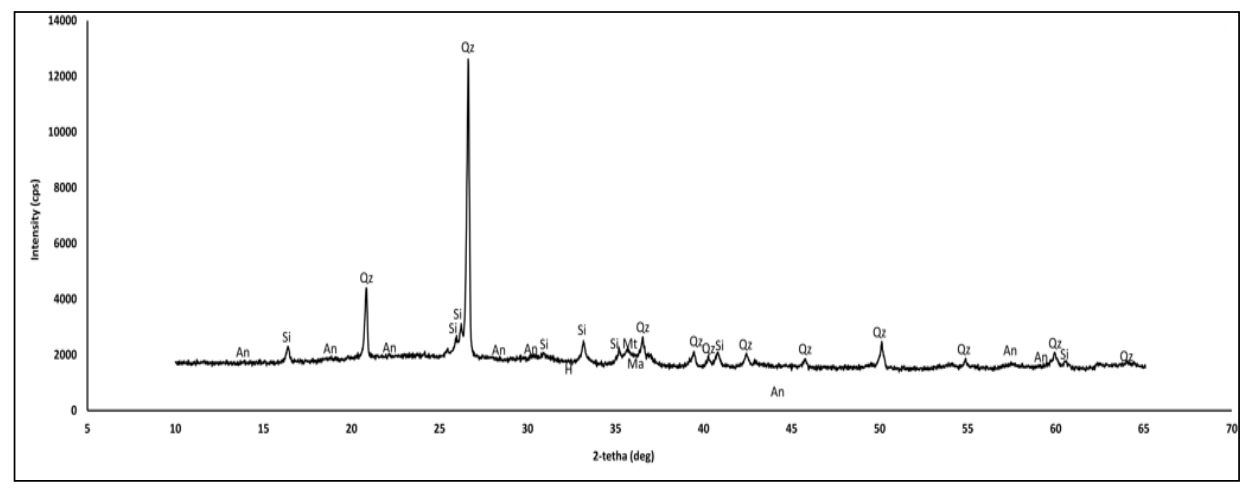

Fig. 1. XRD analysis of fly-ash.

Table 1: Chemical compounds of fly ash from XRD analysis.

\begin{tabular}{|c|c|c|}
\hline Code & Mineral & Chemical Formula \\
\hline 1 & Quartz low & $\mathrm{SiO}_{2}$ \\
\hline 2 & Alumunium Oxide & $\mathrm{Al}_{2} \mathrm{O}_{3}$ \\
\hline 3 & Magnemite & $\mathrm{TiO}_{2}$ \\
\hline 4 & $\begin{array}{c}\text { Hematite HP, iron(III) } \\
\text { oxide }\end{array}$ & $\mathrm{Fe}_{2} \mathrm{O}_{3}$ \\
\hline 5 & Anorthite, sodian & $\mathrm{Na}_{0.45} \mathrm{Ca}_{0.55} \mathrm{Al}_{1.55} \mathrm{Si}_{2.45}$ \\
\hline
\end{tabular}

As shown in Figure 1 and Table 1 the main mineral of fly-ash are quartz, aluminum oxide, iron oxide and anorthite. 
As shown in Table 2, the total quantity of three main oxides $\left(\mathrm{SiO}_{2}+\mathrm{Fe}_{2} \mathrm{O}_{3}+\mathrm{Al}_{2} \mathrm{O}_{3}\right)$ of fly-ash is more than $70 \%$. Therefore, the material is classified as pozzolanic material according to ASTM C618-2012.

Table 2. Chemical composition of fly ash by XRF analysis.

\begin{tabular}{|c|c|c|}
\hline No. & $\begin{array}{c}\text { Oxide } \\
\text { Contain }\end{array}$ & Percentage (\%) \\
\hline 1. & $\mathrm{SiO}_{2}$ & 48,47 \\
\hline 2. & $\mathrm{Al}_{2} \mathrm{O}_{3}$ & 26,05 \\
\hline 3. & $\mathrm{Fe}_{2} \mathrm{O}_{3}$ & 12,54 \\
\hline 4. & $\mathrm{TiO}_{2}$ & 0,92 \\
\hline 5. & $\mathrm{CaO}$ & 5,18 \\
\hline 6. & $\mathrm{MgO}$ & 2,77 \\
\hline 7. & $\mathrm{Cr}_{2} \mathrm{O}_{3}$ & 0,02 \\
\hline 8. & $\mathrm{~K}_{2} \mathrm{O}$ & 1,66 \\
\hline 9. & $\mathrm{Na}_{2} \mathrm{O}$ & 0,47 \\
\hline 10. & $\mathrm{SO}_{3}$ & 1,05 \\
\hline 11. & $\mathrm{Mn}_{2} \mathrm{O}_{3}$ & 0,19 \\
\hline
\end{tabular}

\subsection{Compressive strength}

The specimens were tested for compressive strength at 28 days. The results is shown in Figure 2.

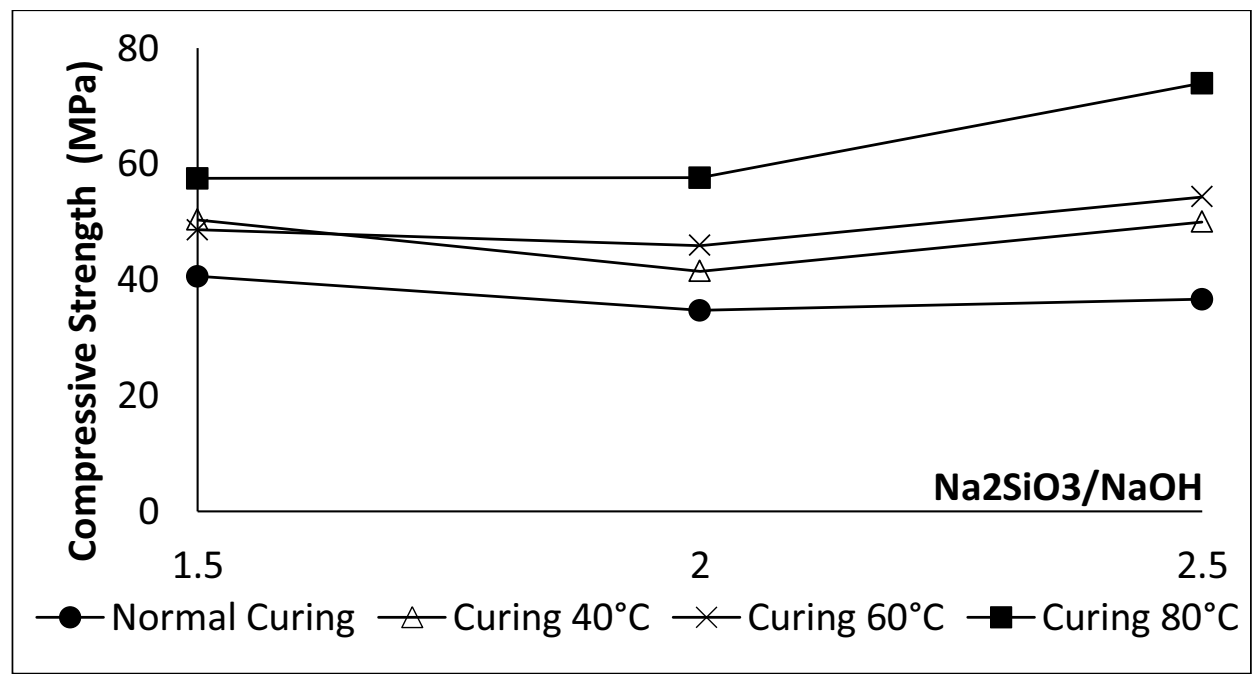

Fig. 2. Influence of curing temperature to the strength.

It is clearly as illustrated in Figure 2 that increasing of curing temperatures improves mechanical strength. The highest compressive strength is achieved at a temperature of $80^{\circ} \mathrm{C}$. Increase of strength at elevated temperature is contributed by acceleration of geopolymerization reaction [1]. Another study explained that the maximum of compressive strength obtained with the curing temperature of $60-80^{\circ} \mathrm{C}$ with a duration of $6-12$ hours [5]. The increasing of compressive strength due to the formation of the crystal lattice at $2 \Theta$ angle in the mids of $5^{\circ}-14^{\circ}$. Increasing of curing temperature even increases compressive 
strength of the concrete with GGBTS (Ground granulated Blas Furnace Slag) as substitution [6]. With the normal curing there were formation of crystall quarts, mullite and magnetite on the $2 \Theta$ angle in the mids of $28^{\circ}-35^{\circ}$ [7]. In this research, geopolymer-based fly ash was more appropriate with a mixture of alkaline activators $\mathrm{Na}_{2} \mathrm{SiO}_{3}$ and $\mathrm{NaOH}$ than only with $\mathrm{NaOH}$ or $\mathrm{Na}_{2} \mathrm{SiO}_{3}$. However, with the increasing mass ratio of $\mathrm{Na}_{2} \mathrm{SiO}_{3}$ to $\mathrm{NaOH}$ the increasing of compressive strength relatively small. The highest compressive strength was achieved at a ratio of $\mathrm{Na}_{2} \mathrm{SiO}_{3} / \mathrm{NaOH}=2.5$, equal to the results of previous study [8]. It seems that contribution of soluble silica from alkaline activator takes part in the geopolymerization process in improving the ratio of $\mathrm{Si}$ to Al. It significantly effects to developing of mechanical properties of concrete [9]. Other study proved that the influence of curing temperature changed the formation of the crystal $[10,11]$, but at longer duration of curing time causes less impact in the formation of crystals.

\subsection{Split tensile strength}

The specimens were tested for splitting tensile strength at 28 days. The results are shown in Figure 3.

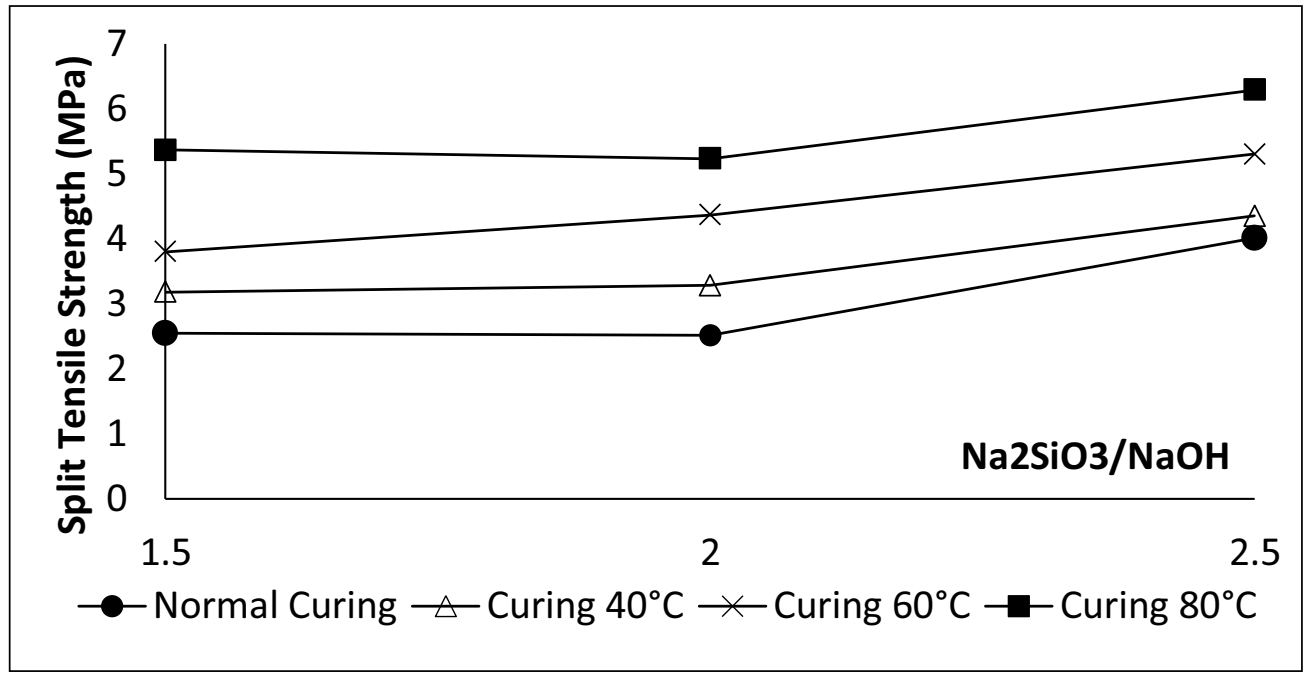

Fig. 3. Influence of curing temperature to the split tensile strength.

Illustration in Figure 3 reveals that the effect of curing temperature in split tensile strength has an equal tendency to the strength. The increasing of temperature curing increases the split tensile strength as well. The highest split tensile strength was achieved at a temperature of $80^{\circ} \mathrm{C}$. The rising of curing temperature even increases the split tensile strength for concrete with GGBFS (Ground Granulated Blas Furnace Slag) as substitution [12]. The highest influence ratio of $\mathrm{Na}_{2} \mathrm{SiO}_{3} / \mathrm{NaOH}$ on split tensile strength was achieved on the ratio 2.5 , similar to the results of previous study [13]. 


\subsection{Closed porosity}

The specimens were measured to obtain closed porosity 28 days. The results are shown in Figure 4.

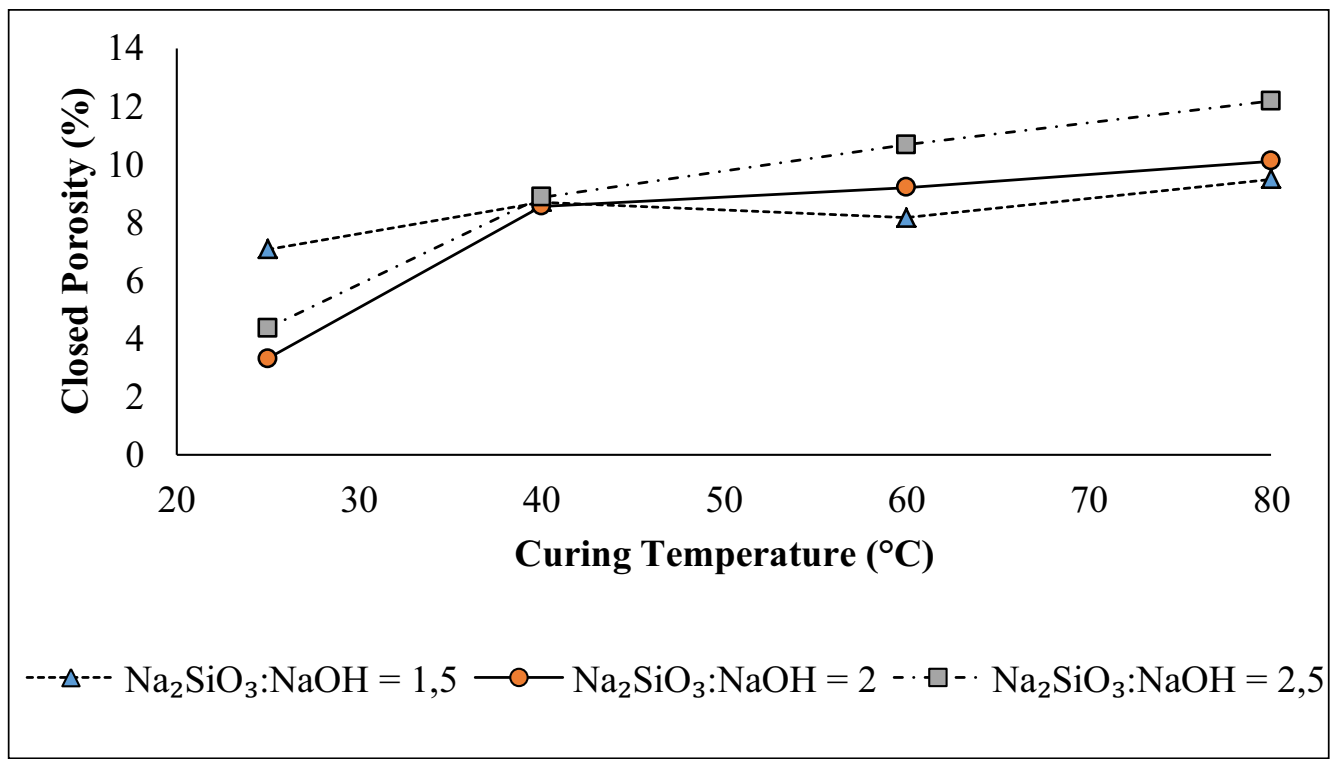

Fig. 4. Influence of curing temperature to the closed porosity.

The influences of increasing curing temperature to the closed porosity have equal tendency to the results of compressive strength. The increasing of curing temperature increases the percentage of closed porosity as well.

\subsection{Elasticity modulus}

The mixtures were tested for determine the modulus of elasticity. The result is provided in Figure 5.

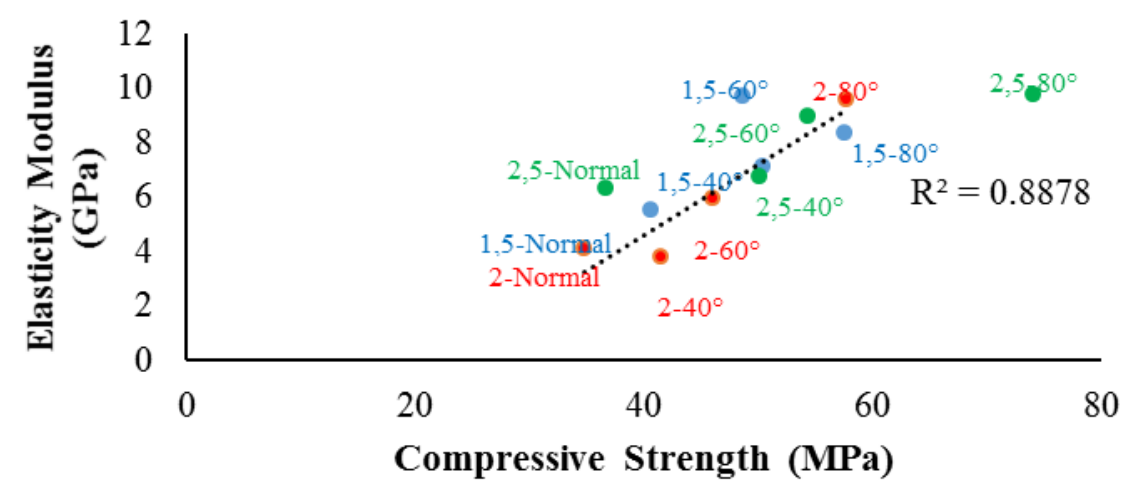

Fig. 5. Graph of elasticity modulus for all mixtures. 
Notes: There are two signs on the chart (numbers - letters $=\mathbf{x}-\mathbf{y}$ ) or (numbers - numbers $=\mathbf{x}-\mathbf{y}$ ). $\mathbf{x}=$ are the ratio of $\mathrm{Na}_{2} \mathrm{SiO}_{3} / \mathrm{NaOH}, \mathbf{y}=$ are the curing conditions

Due to the limitations of existing equipment, each mixture was analyzed for one specimen at 28 days. It is not simple to discuss all existing graph. However it can be explained that increasing temperature of curing promotes the elasticity modulus. The results were corresponding to the results for compressive strength and split tensile strength.

\section{Conclusions}

Curing temperature has a significant effect to increase compressive strength and split tensile strength. The curing temperature enhances the percentage of closed porosity and Elastic Modulus as well. The maximum ratio of $\mathrm{Na}_{2} \mathrm{SiO}_{3}$ to $\mathrm{NaOH}$ to increase the optimum mechanical properties is 2.5. In this composition, the increase of compressive strength is up to $100 \%$, split tensile strength increased up to $56 \%$, and modulus of elasticity increased up to $53 \%$. At a ratio of $\mathrm{Na}_{2} \mathrm{SiO}_{3}$ to $\mathrm{NaOH}=2$ the increase of compressive strength is up to $65 \%$, split tensile strength increased up to $100 \%$, and the increase of modulus of elasticity was up to 133 . For the ratio of $\mathrm{Na}_{2} \mathrm{SiO}_{3}$ to $\mathrm{NaOH}=1.5$ the increase of compressive strength up to $42.5 \%$, the split tensile strength was up to $101 \%$, and the increase of the modulus of elasticity was up to 51

\section{References}

1. J. Davidovits, Geopolymer: Chemistry \& Applications (Institut Geopolymere, France, 2008).

2. S. Kumar, R. Kumar, S.P. Mehrotra, J. Mater. Sci., 45, 607 (2010)

3. D. Hardjito, E.W. Steenie, M.J.S Dody, B. Vijaya Rangan, ACI Material Journal,6, 467 (2004)

4. J.J. Ekaputri, Triwulan, S. Junaedi, H. Fansuri, R. Bayuaji, Materials Science Forum 803, 63 (2015)

5. Frantisek Skvara, Tomas Jilek, Lubomir Kopecky, Ceram. Silik., 49, 195 (2005)

6. J.J. Ekaputri, K. Maekawa, T. Ishida, Mater. Sci. Forum, 857, 305 (2016)

7. Tanakorn Phoo-ngernkham, Akihiro Maegawa, Naoki Mishima, Shigemitsu Hatanaka, Prinya Chindaprasirt, Constr. Build. Mater., 91, 1 (2015)

8. Triwulan, P. Wigestika, J.J. Ekaputri, International Conference on Civil Engineering Research, (2016)

9. M. Rowles, B. O’Connor, J. Mater. Chem., 13, 1161 (2003)

10. E. Arioz, O. Arioz, O. M. Koçkar, Int. J. Chem. Eng. Appl., 496, 423 (2013)

11. S. Apodaca Garcia, S.P. Arredondo Rea, J.M. Gomez Soberon, J.L. Almaral Sanchez, R. Corral Higuera, Int. J. Mater. Sci. Eng., 2, 50 (2015)

12. S. Chithra, G. Dhinakaran, International Journal of ChemTech Research, 6(2), 1516 (2014)

13. M.D.J. Sumajouw, B.V. Rangan, (Curtin University of Technology, 2006) 